\title{
Concept and Management of Nephritis (Waram- i Kuliya) in Unani Medicine
}

\section{Quddusi N1*, Bilal Ahmad', Usama Akram², Mohammad Fazil ${ }^{3}$ and AA Khan ${ }^{4}$}

${ }^{1}$ Research Officer, Scientist-III, Hakim Ajmal Khan Institute for Literary and Historical Research in Unani Medicine, (CCRUM), New Delhi, India

${ }^{2}$ Research Officer, Scientist-I, Hakim Ajmal Khan Institute for Literary and Historical

Research in Unani Medicine, (CCRUM), New Delhi, India

${ }^{3}$ Head of the Institute, Hakim Ajmal Khan Institute for Literary and Historical

Research in Unani Medicine, (CCRUM), New Delhi, India

${ }^{4}$ Director General, CCRUM, Ministry of AYUSH, New Delhi, India

*Corresponding Author: Quddusi N, Research Officer, Scientist-III, Hakim Ajmal Khan Institute for Literary and Historical Research in Unani Medicine, (CCRUM),

New Delhi, India.
Received: July 08, 2020

Published: August 31, 2020

(C) All rights are reserved by Quddusi N., et al.

\begin{abstract}
Unani System of Medicine puts great emphasis on lifestyle management for the promotion of health and prevention and treatment of disease. Therefore, it is of immense relevance to present times as lifestyle diseases are imposing the greatest burden on healthcare. With the changes in the lifestyle, many diseases have emerged in the past few decades. These include diabetes, hypertension leading to kidney failure and other disorders especially in developing countries. Unani physicians have described a number of drugs to strengthen and tone up kidneys. These drugs help in restoring the functions of kidneys. The paper includes the concept of kidney disease with special reference to nephritis, its types and the single drugs along with their evidence based researches.
\end{abstract}

Keywords: Unani; Nephritis; Management; Waram-i Kuliya

\section{Introduction}

With the changes in the lifestyle, many diseases have emerged in the past few decades. These include diabetes, hypertension leading to kidney failure and other disorders especially in developing countries. The incidence of Chronic kidney Diseases (CKD) or Kidney Failure has doubled in the last 15 years. In India, there are approximately 7.85 million people are suffering from Kidney diseases and this is a global threat to health in general and for developing countries in particular, because therapy is expensive and life-long. Worldwide, 850 million people are now estimated to have kidney diseases from various causes and chronic kidney disease causes at least 2.4 million deaths worldwide per year and is now the 6 th fastest growing cause of death. And these are the numbers when the cases in India, which is home to world's 17 percent population, remain largely undocumented and unregistered. The alarming figures cited above are just a glimpse of the sobering reality that renal failure and other kidney-related diseases are more common than we would like to believe. And more often than not, the preventive actions required to guard against kidney diseases are minor lifestyle changes that also contribute to an overall healthy lifespan. The theme for 2019 World Kidney Day was "Kidney health for everyone everywhere", aiming to highlight the growing burden of kidney disease and kidney health disparity and inequity worldwide. The day was first observed in 2006 with 66 countries marking the event with various awareness raising programmes. Within two years, this number rose to 88 .

Unani System of Medicine puts great emphasis on lifestyle management for the promotion of health and prevention and treatment of disease. Therefore, it is of immense relevance to present times as lifestyle diseases are imposing the greatest burden on healthcare. The System prescribes a large number of drugs for preventive purposes. Not only this, concept of using organ and system specific tonics is also a unique feature of this system. Unani physicians have described a number of drugs to strengthen and tone up kidneys. These drugs help in restoring the functions of kidneys. Apart from these preventive and strengthening drugs, the system has got a treasure of drugs for protecting the kidneys and treating kidney disorders. 


\section{Concept of function of kidneys in unani medicine}

As per Unani Medicine, every organ of the body has definite Faculties (Quwa): Faculty of Nutrition (Quwwat i Ghaziya) of the body has been divided into four powers i.e. Faculty of ingestion (Quwwat i Jaziba), Faculty of retention (Quwwat i Masika), Faculty of digestion and Transformation (Quwwat i Hazima), Faculty of Excretion (Quwwat i Dafiah). All these four powers are found in all the cells of the body which absorb the food materials and Pneuma (Ruh) and metabolise and transform them into various compounds and replace the wear and tear and produce the energy for the proper functioning of different Faculties (Quwa). Faculty of Excretion (Quwwat i Dafiah) helps in excretion of waste products i.e. those products which after metabolism cannot be transformed into good humours. Waste materials produced during liver metabolism (Hazm i Kabidi) and Tissue or cellular metabolism (Hazm i Uzwi) are expelled out by the kidneys and skin in the form of urine and sweat [1].

When the blood passes through the kidneys most of the substances not needed to the body are removed from the blood. These include waste products produced during the course of metabolism, excess of electrolytes and water at first everything except colloid material of the plasma (Sail al dam) is filtered through the glomeruli of the kidneys, then selective reabsorption of various materials take place accordingly as per the temperament of the body. This power of selective reabsorption is known as Quwwat i Mumayyizah. This is a special power of kidneys by which the kidneys separate urinary waste products from the blood [2].

If any of the above said five faculties become weak then it affect the nature of waste products to be excreted out. If Faculty of Nutrition (Quwwat i Ghaziya) becomes poor, nutrition from blood which comes to the kidney will not be picked up by them and ultimately it eliminates via urine. If Faculty of retention (Quwwat i Masika) becomes weak, kidneys will not be able to hold watery content and eliminate it with the urine. This sudden loss of watery content deprived the kidneys and it causes further absorption of the blood and this cycle continues. In the last stage when power of selective reabsorption (Quwwat i Mumayyizah) becomes poor, then the kidney is not able to discriminate the matter contained in watery content. In this condition, they leave some important substances which should have been reabsorbed. The power of separation is responsible for the ultrafiltration and reabsorption in kidneys [3].

\section{Concept of Nephritis (Waram-i Kuliya) in unani medicine}

According to the Unani System of Medicine, diseases are broadly classified into two i.e. Single disease (Amraz i Mufradah) and Compound disease (Amraz i Murakkiba). Single disease (Amraz i Mufradah) is further divided into: Temperamental diseases (Amraz i Sue Mizaj), (Structural diseases) Amraz i Tarkeeb, (Loss of continuity) Tafarruq ittisal. Normal temperament of the kidney is Hot and Wet.
Any deviation from the normal temperament causes (Impairment of Temperament (Sue mizaj) [1,4]. Sometimes normal structure of the kidneys is altered. These conditions are included under (Structural diseases) Amraz i Tarkeeb [4]. Any type of trauma and the conditions thereafter are included under (Loss of continuity) Tafarruq ittisal. Nephritis (Waram-i Kuliya) comes under Compound disease (Amraz i Murakkiba), as this include all three types of Amraz i Mufradah in it. Nephritis (Waram- i Kuliya) is the inflammation of kidneys that can be hot or acute (Haar) or cold or chronic (Barid). This type of inflammation may involve one or both kidneys at a time [6-8]. It may be caused by congestion of body or those organs that are in close association with kidneys, quantitative and qualitative plethora of matter, renal calculi, trauma, tying of heavy weight on back and diversion of morbid matter from other organ towards kidney.

The site of nephritis (Waram- i Kuliya) can be Parenchyma of Kidneys, Interstitial spaces or externally due to the inflammation of intestines, ureters etc. Sometimes this involves only one kidney and sometimes both in some parts or the whole kidney. This inflammation either resolves or matures to form pus or hardens. Hardening of kidneys or hard inflammation of kidneys (Waram-i KuliyaSulb) which according to matter, hard to mature and melancholic in nature occurs due to improper management of acute and chronic inflammation. Treatment of hard inflammation of kidneys is very difficult and leads to ascites and tubercular fever. So a universal principle of treatment for all types of nephritis (Waram- i Kuliya) is to save it from being hardened as hard inflammation (Waram-i KuliyaSulb) is very difficult to treat or manage [5]. It is also necessary to avoid potent resolvents (Muhallilat) and diuretics (Mudirrat) initially. Vomiting (Qai) or diversion of matter and purgation (Talin-i Taba') is beneficial. Sitz bath (Abzan) with the decoction of Iklil al Malik (Melilotus alba Desr.), Babuna (Matricaria chamomilla Linn.), Sabus Gandum(Husk of Triticum aestivum Linn.), Jao muqashshar (Hordeum vulgare Linn.), Mako (Solanum nigram Linn.), Tukhm-i Khatmi (Althaea officinalis Linn.) is beneficial for every type of inflammation of kidneys [5].

\section{Acute nephritis (Waram-i KuliyaHaar)}

It is caused by the predominance of thick blood or Yellow Bile (Safra). It is characterized by pain, heaviness on the affected side, excessive thirst, sleeplessness, Irregular fever, bilious vomiting, difficult micturition, mental confusion and swelling of the affected side. Its principles of treatment are Alleviation of pain (Taskeen i Alam), resolution of inflammation/swelling (Tahlil i Waram), evacuation of yellow bile (Tanqia i Safra) [6-8]. Regimenal therapy for this type of inflammation include Bloodletting through Basilic vein on the affected side, Bloodletting through Sapheanous vein, Bloodletting through Popliteal vein ${ }^{7}$.The diet therapy plays a major 
role in Unani Medicine. Some of the diets that are recommended in this disease are food stuffs which are easy to digest but have little nutritional value and produce such a sanguine which is normal in viscosity e.g. garlic, raddish, spicy and salty fishes, etc. (Aghziya Latifa), Honey water (Maa al Asl) [10], Hareerah [7], Barley water (Maa ash shaeer) [9]. The diets or foods restricted in this condition are Salty and Sour diets, Acidic diets and purgatives [9], Meat, Sweet diets [7].

\section{Chronic nephritis (Waram-i Kuliya Barid)}

It is caused by the predominance of phlegm (Balgham). It is characterized by mild pain, heaviness accompanied with tension, puffiness of face and swelling of the body. Its principle of treatment are evacuation of phlegm (Tanqia i Balgham) followed by diuresis (Idrar) and heat production in kidneys (Taskhin i Kuliya) [6-8]. Regimenal therapy for this type of inflammation include Enema (Huqna) with Roghan i Ghaar (Laurus nobilis Linn.) [7].

\section{Hard nephritis (Waram-i KuliyaSulb)}

Non resolution of acute nephritis (Waram-i Kuliya Haar) and Chronic Nephritis (Waram-i Kuliya Barid) sometimes lead to Hard Nephritis (Waram-i Sulb) in which there is accumulation or predominance of Black Bile (Sawda) in the kidneys. It is characterized by severe heaviness, numbness of lower part of the body, renal debility, watery urine and it may lead to ascites and this condition is usually fatal. Its principles of treatment include evacuation of black bile (Tanqia i Sawda) and softening of kidneys (Tamreekh i Kuliya) [6-8]. Regimenal therapy for this type of inflammation include Enema (Huqna) with decoction of Babuna (Matricaria chamomilla, Linn.), Kirnab (Brassica olearacea, L.), Nakhuna (Trigonella uncata, Boiss), Tukhm-i Khatmi (Althaea officinalis, Linn.), Saboos- i Gandum (Triticum aestivum, Linn.) and vomiting (Qay) [12].

Single drugs used in the management of Nephritis (Waram-i Kuliya)

\begin{tabular}{|l|l|}
\hline Name of the Unani Drug & $\begin{array}{l}\text { Refer- } \\
\text { ences }\end{array}$ \\
\hline $\begin{array}{l}\text { Rateenaj (resin) - Orally for Acute Nephritis (Waram-i } \\
\text { KuliyaHaar) }\end{array}$ & {$[6,13]$} \\
\hline $\begin{array}{l}\text { Ab i Barg i Mako Sabz Murawwaq (juice of leaves of } \\
\text { Solanum nigram Linn.) -Orally for Acute Nephritis } \\
\text { (Waram-i KuliyaHaar) }\end{array}$ & {$[6,14]$} \\
\hline $\begin{array}{l}\text { Ab i Barg i Kasni Sabz Murawwaq (juice of leaves of } \\
\text { Cichorium intybus Linn.) - Orally for Acute Nephritis } \\
\text { (Waram-i KuliyaHaar) }\end{array}$ & {$[6,15]$} \\
\hline $\begin{array}{l}\text { Maghz Amaltas (pulp of Cassia fistula Linn.) - Locally as } \\
\text { Enema (Huqna) for Acute Nephritis (Waram-i Kuliya- } \\
\text { Haar) }\end{array}$ & {$[8,16]$} \\
\hline
\end{tabular}

Maghz Amaltas (Cassia fistula Linn.) - Locally as Zimad and Huqna for Chronic Nephritis (Waram-i Kuliya Barid)

Ab i Kadu (juice of Cucurbita moschata (Duchesne) Poir.) -Locally for Acute Nephritis (Waram-i KuliyaHaar)

Sandal (Santalum album Linn.) - Locally for Acute Nephritis (Waram-i KuliyaHaar)

Dhania Sabz (fresh Coriandrum sativum Linn.) - Locally for Acute Nephritis (Waram-i KuliyaHaar)

Lehsun (Allium sativum) - Orally for Acute Nephritis (Waram-i KuliyaHaar)

Kharbaq (Helleborus niger Linn.) - Orally for Acute Nephritis (Waram-i KuliyaHaar)

Darchini (Cinnamomum zeylanicum Blume) - Orally for Acute Nephritis (Waram-i KuliyaHaar)

Halun (Lepidium sativum Linn.) - Orally for Acute Nephritis (Waram-i KuliyaHaar)

Babuna (Matricaria chamomilla Linn.) - Locally as Natul for Acute Nephritis (Waram-i KuliyaHaar)

Babuna (Matricaria chamomilla Linn.), - Locally for Chronic Nephritis (Waram-i Kuliya Barid)

Babuna (Matricaria chamomilla Linn.) - Orally Waram-i KuliyaSulb

Khatmi (Althaea officinalis Linn.) - Locally as Natul for Acute Nephritis (Waram-i KuliyaHaar)

Nammam (Ocimum canum Sims) - Locally for Chronic Nephritis (Waram-i Kuliya Barid)

Barg i Ghaar/ Ghaar (Laurus nobilis Linn.) - Locally for Chronic Nephritis (Waram-i Kuliya Barid)

Marzanjosh (Origanum vulgare Linn.) - Locally for Chronic Nephritis (Waram-i Kuliya Barid)

Ab i Maweez (juice of Vitis vinifera Linn.) - Orally for Chronic Nephritis (Waram-i Kuliya Barid)

Ab i Turanjbin (juice of Alhagi maurorum Baker Dexv) - Orally for Chronic Nephritis (Waram-i Kuliya Barid)

Sudab (Ruta sylvestris Mill) - Locally as Zimad and Huqna for Chronic Nephritis (Waram-i Kuliya Barid)

Nakhuna (Pods of Trigonella uncata, Boiss.) - Locally for Hard Nephritis (Waram-i KuliyaSulb)

Tukhm i Katan (seeds of Linum usitatissimum Linn.) Locally for Hard Nephritis (Waram-i KuliyaSulb)

Khasak (Tribulus terrestris Linn.) - Orally for Hard Nephritis (Waram-i KuliyaSulb)

Bisfayej (Polypodium vulgare Linn.) - Orally for Hard Nephritis (Waram-i KuliyaSulb)

Zufa ratab (Nepta orientalis) - Locally for Hard Nephritis (Waram-i KuliyaSulb)

Murr (Commiphora myrrha)- Orally and Locally for Hard Nephritis (Waram-i KuliyaSulb)

Table 


\section{Conclusion}

From the above, it may be concluded that Unani medicine has a detailed description of functions of kidneys and its diseases in its classics. Furthermore, it has a great potential for the treatment of nephritis (Waram- i Kuliya) and its types. Modifications in diet and regimenal therapies described in Unani Medicine help in changing the lifestyle which is a key factor in causing kidney diseases. Single drugs that are mentioned in this paper have a clear evidence of their potential in nephritis (Waram-i Kuliya). These drugs are proven to have nephroprotective effect in scientific studies that are recorded, so it is quite evident that they can be used to treat nephritis in one way or other. There is a need to scientifically evaluate the regimenal therapies mentioned in this paper so that their strength may be used to treat nephritis (Waram- i Kuliya).

\section{Bibliography}

1. Ibn Zuhr. Kitab al-Taysirfi'l-Mudawawa-al-Tadbir (Urdu Translation), Central Council for Research in Unani Medicine, New Delhi (1986): 158-159.

2. Ahmed SI. An Introduction to alUmur al Tabi'yah Principles of Human Physiology in Tibb, Central Council for Research in Unani Medicine New Delhi (2009): 180-181.

3. Ibn Rushd. Kitab al Kulliyat, (Arabic), Central Council for Research in Unani Medicine New Delhi 28 (1984): 247-248.

4. Ibn Sīnā H. 1408 al-Qanun fi'l-Tibb, (Arabic). Jamia Hamdard, New Delhi: 732-739.

5. Kabiruddin M. Al-Iksir, Vol. II, Ejaz Publishing House, New Delhi (2003): 1175-1184

6. Nafis Ibn Iwaz, 1326 H., Sharah asbaab wa alaamaat, (Arabic), Matba'Nami Munshi Naval Kishor, Lucknow 2. 60-62.

7. Ibn Sina, 1411 H., al-Qanoon fi'l-Tibb, Vol. III, part-2, (Arabic), Jamia Hamdard, p. 732-739.

8. Baghdaadi, Ibn Hubal, 1363 H., Kitab al Mukhtaraat, Vol.III, (Arabic), Daira al Maarif al Usmaniyya, Hyderabad 411-412.

9. Khān M A. Iksir-i A'zam, Matba' Nami Munshi Naval Kishor, Lucknow 3 (1906): 425-434.

10. Razi Muhammad b. Zakariyya, 2002, Kitab al HawiVol.10, (Urdu Translation), Central Council for Research in Unani Medicine, New Delhi, p.39-42.

11. Khan M A. Rumuz-i A'zam, New Delhi, Central Council for Research in Unani Medicine New Delhi 2 (2006): 134-136.

12. Razi Muhammad. Zakariyya. Kitab al Mansuri (Urdu Translation), Central Council for Research in Unani Medicine New Delhi (2010): 379-380.

13. Alam M., et al. "Effect of oleo-gum-resin of Boswellia serrata (Kundur) on renal function in albino rats". Indian Journal of Traditional Knowledge 10.4 (2011): 736-740.
14. Fariba Azarkish., et al. "Effect of administration of Solanum nigrum fruit on prevention of Diabetic Nephropathy in Streptozotocin induced Diabetic rats". Pharmacognosy Research 9.4 (2017): 325-332.

15. Khaliq T., et al. "Nephroprotective Potential of Rosa damascena Mill Flowers, Cichorium intybus Linn Roots and Their Mixtures on Gentamicin-Induced Toxicity in Albino Rabbits". Pakistan Veterinary Journal 35 (2013): 43-47.

16. Kalantari H., et al. "Protective effect of Cassia fistula fruit extract on bromobenzene-induced nephrotoxicity in mice". $\mathrm{Hu}$ man and Experimental Toxicology 30.10 (2011): 1710-1715.

17. Ullah N., et al. "Nephroprotective property of Cinnamomum zeylanicum and its antibacterial activity in combination with gantamicin". Pakistan Journal of Pharmaceutical Sciences 30.1 (2017): 55-60.

18. Mustufa Cemek. "Antihyperglycaemic and anti-oxidative potential of Matricaria chamomilla Linn. in streptozotocin induced diabetic rats". Journal of Natural Medicines 62.3 (2008): 284-293.

19. Sayyah M. "Analgesic and Anti-inflammatory activity of the leaf, essential oil of Laurus nobilis Linn". Phytotherapy Research 17.7 (2003): 733-736.

20. Arvind kumar E. "Renoprotective effect of Linum usitatissimum seeds through haemodynamic changes and conservation of antioxidant enzymes in renal ischaemia-reperfusion injury in rats". Arab Journal of Urology 9.3 (2011): 215-221.

21. Anusuya N., et al. "Nephroprotective effect of ethanolic extract of garlic (allium sativum l.) on cisplatin induced nephrotoxicity in male wistar rats". Asian Journal of Pharmaceutical and Clinical Research 6.8 (2013): 97-100.

22. Raj Kumar Vaya. "Nephroprotective action of T. terrestris Linn and Crataeva nurvala Buchman in Albino rats". Indian Journal of Pharmacology 33 (2001): 124-145.

\section{Assets from publication with us}

- Prompt Acknowledgement after receiving the article

- Thorough Double blinded peer review

- Rapid Publication

- Issue of Publication Certificate

- High visibility of your Published work

Website: www.actascientific.com/

Submit Article: www.actascientific.com/submission.php Email us: editor@actascientific.com

Contact us: +919182824667 